\title{
SELF-TRUST IN CONNECTION WITH EMPATHY IN DIFFERENT SOCIAL SITUATIONS OF DEVELOPMENT IN ADOLESCENCE
}

UDC: 159.922 .27

\section{Danilova Yulia \\ PhD in psychological sciences, Saint Petersburg State University, Saint Petersburg (Russian Federation) \\ ORCID ID: https://orcid.org/0000-0001-7687-0393}

\begin{abstract}
ABCTRACT. The article analyzes the level of self-trust in connection with empathy intensity level in different social situations of development in adolescence. Characteristics of self-trust in important spheres of life and empathy towards different categories of people in adolescents, living in complete and incomplete families, and also in orphanages were studied. The sample: 286 adolescents from SaintPetersburg, Russia, aged 14-16 (126 boys;160 girls), including 97 orphanage teenagers (46 boys; 51 girls), 104 full families children (53 boys; 51 girls); 85 single-parent families children (40 boys; 45 girls). Selftrust survey by T.P.Skripkina was used to investigate self-trust level in significant spheres of life in adolescents. Empathy diagnostics by I.M.Yusupov was used to measure empathy level toward different people in adolescents. Data analyses included descriptive statistics analysis, Student's t-test, correlation analysis by Spirmen.Results of our study indicate, that self-trust in adolescence is not equally manifested in various spheres of life. Self-trust is expressed less in problematic areas: educational and relations with the opposite sex. Self-trust in the areas of relationships with peers and a family is expressed at the highest level. Social situation of development influences on self-trust: adolescents from full families, all indicators of selftrust are higher. The focus of empathy also varies among adolescents from full families and those who have experienced trauma of parting with parents. The findings showed the importance of not only the presence, but also the composition of the family for successful emotional development in adolescence.
\end{abstract}

Key words: adolescence, self-trust, empathy, parental deprivation, family, orphanage, social situation of development.

\section{Problem definition}

The problem of trust at all and self-trust as a part becomes extremely significant in changing environment conditions. That is why it is important to know its mechanisms, predictors, corre- lations from different perspectives. We should pay our attention on it from the very childhood, building constructive relationships with significant adults, and further on this base - building relationships with others and ourselves. The environment, 
for sure, influences on trust development and our goal is to know, how it happens and how to control it. Because lack of self-trust leads to selfdoubt, aggressive behavior, autoaggression, depression, delinquent behavior, especially in adolescence. Empathy is one of the important components of constructive development and behavior, without which self-trust cannot be built. The ability to recognize feelings of other people means the ability to navigate in the social world and interact in actual situations competently and constructively. The question of correlations between empathy and self-trust in adolescents is studied insufficiently. The features of self-trust of adolescents in different social situations of development have not been studied, the role of empathy in the development of self-trust has not been determined neither in families nor in orphanages. Thus, summing up the above, the problem of self-trust and empathy in adolescence is an individual problem of every teenager, as well as the root problem of interaction between individual and society and the functioning of society at different levels (macro -, meso - and micro-social situation of development).

\section{Analysis of recent research and publications Trust and self-trust}

The research of trust phenomenon was conducted by scientists of different directions. At this stage of study the concept of trust is also defined in different ways. Based on the results of content analysis of the most frequently mentioned trust definitions, there are several main ones:

1) trust is closely related to attitudes, expectations, beliefs;

2) trust is shown in relation to different objects and subjects;

3 ) trust is often defined through an act of behavior, thus highlighting the activity aspect of trust: the action of the subject as a way of showing trust;

4) trust includes the results of the investigation and the provision of trust (the partner's action can be predicted and assessed positively by the subject of the trust (Castaldo, S, 2002).

Trust in human relationships (interpersonal trust) is generalized expectation of a person, that one can rely on the promises, words, oral or written statements of another person or group. Since we are talking about expectations regarding interactions, the indicator of trust should be evaluated from the point of view of society. Trust is always formed on the basis of interpersonal interaction. (Rotter J, 1980). E. Ullman-Margalit believes that trust can be formed only in relation to someone (Ullmann-Margalit E., 2001. ).

In modern psychological science, it is customary to distinguish between trust in others and self-trust in a certain activity (Skripkina T.P., 2000; Golub O.V., 2004). According to E. Erikson, basic trust is formed by the age of 1 year, if the child has a stable sense of security, which is provided by the mother or a substitute person (Erikson E., 1995). Interpersonal and social trust 
is built on the basis of the formed basic trust. In the study of the dynamics of self-trust and trust to others, conducted by O. V. Golub (Golub O.V., 2004) was shown that self-trust in early adolescents of 10 years is directly related to trust to others, but not to trust to themselves. That is, at this age, there is no direct relationship between selftrust and trust to others. In other words, for selftrust, a 10-year-old child still needs to rely more on others than on himself. At the age of 12, there is a direct relationship between the concepts of "trust to others" and "self-trust" as components of the concept of trust. By the age of 14, a distinction is found between the concepts of "trust in oneself", "trust in others", "self-trust", which form a single, integral central formation of the phenomenon of trust.The analysis of studies also shows that by the age of 14 there is a separation of self-acceptance and self-trust from trust to others. Maturation and separation of self-trust occurs at the end of adolescence, but an extremely significant and crucial moment associated with its formation can be called the age of about 12 years.

So, self-trust is understood as an attitude, an expectation of own success in various spheres of life, including knowledge about own capabilities, skills, and a sense of security in these areas. Self-trust inextricably exists together with trust to others, the prevalence of one of these spheres leads to the disharmony of the individual. An important feature of trust is that its object should be potentially safe and relevant for the trust subject (Skripkina T.P., 2004).

\section{Empathy in adolescence}

Numerous researches show the importance of compassion and empathy for the full development of personal and constructive social relationships. The development of such characteristics as empathy is one of the most important layers of personality formation, providing morality development (Isaaks J., 2015; Jalava J., 2003; Jones D.C., 1991; Baron-Cohen S., 2004; Bozhovich L.I., 2005). Empathy is the ability to give an emotional response to the state of another: correctly recognize the emotional state, compassionate, seek to help. One of the most important tasks of adolescence is to establish friendly relations, involving a desire to understand and accept another. It determines the intimate-personal nature of relations with peers, and further with significant adults (Reis, F, 2010). The purpose of empathy is to penetrate into the inner world of another person. The phenomenon of empathy has sociopsychological roots and a multilevel structure with psychological, psychophysiological, sociopsychological levels, has the form of property, process and state. Empathy is important for the character formation, the individual's relationships to the world, to himself, to society. Empathy regulates the process of interaction in it.

\section{Adolescence as a complicated critical}

\section{period of development}

Adolescence is a difficult stage of change in all areas of human life and is deeply studied in psychology (Garland A.F., 1994; Jones D.S., 1991; Karabanova O.A., 2010; Starr L.R., 2008; 
Vangelisti A.L., 1997). The core of personality development in adolescence is communication with peers. Any teenager tries to take a satisfying place in the team, but this is not always possible. For many modern teenagers, the problem of lack of trust is actual. And this distrust can be allencompassing if teenagers don't trust themselves, other people (teachers, parents, peers), or the world at all. Thus, the main task of adolescence is under attack.

It is also extremely important for a teenager to have own place in the family. When parents pay attention on a teenager's increased opportunities and needs, trust him, respect him as a person, are honest with him even in the most unpleasant moments, help to overcome difficulties in knowledge and to establish constructive relationships with people, keep in touch with him, answer numerous questions, thus parents provide favorable conditions for the further development of the child. If the basic trust was not formed in early childhood, the teenager will not be able to find support in his family, and will seek it outside (Reis F., 2010).

Special attention should be paid to the crisis of adolescence, which can be associated with changing in the psychological status of a person. The most important factor affecting the emergency situation of the adolescent crisis is dissatisfaction with himself physically. The imbalance of past ideas about yourself and the current image is the main content of psychological crisis. Dissatisfaction can reach such a high degree that there are insurmountable, obsessive, oppressive thoughts about yourself, anxiety and fears. A critical attitude towards oneself, which only aggregates the psychological picture remains (Reis F., 2010)

Social situation of development and psychological features of Orphanage teenagers

Social situation of development an important plays a big role in adolescence. Social situation of development is a system of circumstances, situations, conditions, institutions of socialization, socialization to social values and standards (Kindermann Th., 1988; Havighurst R., 1972; Baltes P., 1987). Man interacts with the outside world at the level of the microsystem (relations in the family, school, University), mesosystem (relations of several elements of the microsystem), exosystem (social structures that are not the immediate environment of the individual, but affect it) and macrosystem (culture in which man lives) (Bronferbrenner U., 1976).

Social situation of development dictates the whole style of life in childhood, child's social existence and features of consciousness. The social situation of development at each age segment puts before a person specific tasks of development, the resolution of which is the essence of psychological development. The results of child's mental development are in conflict with the established, previous social situation of development, which leads to the resolution of the past and the construction of new relationships with the environment, and thus to a new social situation of development (Kurdek L.A., 2002). Uneven 
change in the social situation of development is one of the fundamental components of agerelated developmental crises.

The basic situation of personal development is formed within the family. It is believed that a full family is an important condition for the successful emotional, cognitive and personal development. Living in a single-parent family carries a number of difficulties. But the greatest difficulties in adaptation, socialization, formation of skills of constructive relationships are experienced by pupils from orphanages, where children have no experience of life in a parent family (Prikhozhan A.M., 2007). It is particularly important to emphasize the role of parent-child relations in the development and formation of personality. Features of child-parent relations are manifested in upbringing style, level of control, level of empathy toward child, emotional closeness of family members, perception of the relationship in the family by the child and parents, conflicts in family, encouragements and punishments, parent's confident and consistent in relation to the child. All of the above features of child-parent relationships seriously affect child's psycho-emotional well-being, self-esteem, nature of coping behavior, ability to self-control and independence. Of course, the greatest influence of parent-child relationships on the personality falls on the period of pre-school childhood (Baltes P., 1987; Benenson J.F., 2008; Garland A.F., 1994; Karabanova O.A., 2010; Rottenberg A.J., 1991; Starr L.R., 2008).
Many studies show that one of the main causes of emotional oppression of adolescents is the loss of emotional contacts with parents (Vangelisti A.L., 1997). There is a deformation of emotional, personal, motivational spheres, psychosomatic disorders in terms of family deprivation in adolescents. An incomplete family is extremely vulnerable in terms of upbringing. Based on statistics, it can be said that most criminals have grown up in single-parent families. Also, the atmosphere of a single-parent family increases the risk of alcohol abuse by adolescents. Adolescents from single-parent families have hypertrophied increased emotionality, vulnerability. Such teenagers can be rude, irritable, uncommunicative, uninterested. It was also found that adolescents from complete families have higher selfesteem than adolescents from incomplete families (Prikhozhan A.M., 2007).

When considering the social situation of the development in adolescent's from orphanages, we should pay attention to paternal deprivation. Psychological deprivation is understood as insufficient satisfaction of basic psychological needs over a long period and to a large extent. Pupils of orphanages suffer not only from deprivation, but also from satiation with social contacts. D. Prug notes that in a situation where adults are constantly changing, a child can restore interrupted emotional contact no more than four times, otherwise he will no longer strive for such contacts and will become indifferent to them (Langmeyer I., 1991). The type of personality 
that is formed from birth in conditions of maternal deprivation, is designated as "emotionless character". It involves intellectual delay, inability to enter into serious relationships with other people, lethargy of emotional reactions, self-doubt, aggressiveness.

An insufficient formation of basic trust in the early stages of life is the first, most important and intractable consequences of maternal deprivation. This leads to serious violations in the emotional development of the child and teenager. The unrealized need for love and acceptance is the cause of many serious developmental disorders. Adolescents poorly differentiate their emotions and experiences, show personal immaturity and egocentrism, which is more typical for a younger age. They often are characterized by a negative and low level of self-esteem, they often do not know and do not accept themselves as a person (Furmanov I.A., 2009). Teenagers from orphanages are characterized by a small activity in real situations of communication, reduced emotionality, weak expression of their experiences. Despite the fact that the opportunity to communicate with peers is presented in more than sufficient volume, children from orphanages do not have the proper development of meaningful and emotional spheres of interpersonal relations, main place is occupied by functional-role communication (Prikhozhan A.M., 2007).

\section{Method}

\section{Study Sample}

The objectives of our research are to study self-trust, empathy in adolescence and correlations between these parametres in different social situations of development. The study involved 286 adolescents aged 15-16 years, of which 77children from the orphanage, 144-from full families, 65-from single-parent families.

\section{Measures}

To solve the set tasks we used the following scales presented in random order:

- Reflective questionnaire by Skripkina

T.P. (adapted for adolescents).

We used the Skripkina T.P. questionnaire, to study self-trust, which was modified for adolescents. Respondent fills in the table, which contains the designated vital areas, using the scale of assessments, where: 5 - "fully trust", 4 - "rather trust", 3 - "partially trust", 2 - "do not trust", 1 "rather do not trust", 0 - "completely do not trust". The data are formed in 11 scales, which reflect the degree of self-confidence in different areas of life: self-trust in educational activity, in intellectual activity, in everyday life (domestic issues), in the ability to build relationships with friends, with younger pupils, with teachers, in the family, with young children, with parents, with representatives of the opposite sex, in the ability to have fun. Teenagers from the orphanage also evaluated the level of self-trust in their relationship with their parents: either with one or both, or with the close adult who had replaced their moth- 
er (for example, grandmother). If the teenager does not know his parents, he evaluated his selftrust in the relationship with the tutor.

The measure of self-trust in certain parameters is estimated on the basis of three levels: high (4-5 points, fully trust); average (2-3 points, partially trust) and low (0-1 points, do not trust). We also calculated the overall level of self-trust on all 11 scales, the maximum level of self-trust is 55 points (Skripkina T.P., 2000).

- Empathy Diagnostics by Yusupov I.M. The technique involves the diagnosis of empathic tendencies level. Respondent must answer (agreeing or not) to each of the 36 statements, evaluate the answers as follows: when answering: "I do not know" - 0 points, "no, never" - 1, "sometimes" - 2, "often" - 3, "almost always" - 4 and when answering: "Yes, always" - 5 points [173]. The sum of points is calculated. Test results can be trusted if the respondent gave no more than three insincere answers displayed in the lie scale. With the sum of 82 to 90 points a person has a very high level of empathy, from 63 to 81 points-a high level, from 37 to 62 points-an average level, from 12 to 36 points-a low level, 11 points and less-a very low level of empathy.

The technique includes the following scales: showing empathy towards parents; animals; elderly; children; heroes of works of art; strangers and unfamiliar people; general level of empathy.

It is also calculated the level of empathy on the scales: 15 points - very high, 13-14 points
- high, 5-12 points - medium, 2-4 points - low, 01 point - very low level of empathy (2004).

\section{Design}

The study used a set of theoretical and empirical methods. Theoretical: analysis and generalization of philosophical, sociological and psychological literature devoted to the problems of trust and self-trust in adolescence. Descriptive statistics of the data obtained by measuring the level of self-trust and empathy were carried out. Further, the comparison of self-trust average meanings in the groups divided by the social situation of development (full family, single-parent family and children's home) was carried out by using t-Student criterion. The comparison of different parameters of empathy average meanings in the groups divided by the social situation of development was also carried out. After it, correlation analysis by Pearson between self-trust and empathy was done in three groups of respondents, devided by social situation of development. Mathematical and statistical analysis was carried out using the statistical package SPSS 20.0.

\section{Results}

\section{Self-trust manifestations in adolescence}

According to the results of the reflexive questionnaire by Skripkina T.P. we can say, that self-trust in the ability to build relationships in the family (4.28), with friends (4.26), in the ability to have fun (4.22), in intellectual activity (4.04) is highly expressed in the whole sample. The fol- 
lowing indicators were the least pronounced: selftrust in the ability to build relationships with teachers (3.92), primary school pupils (3.85) and with representatives of the opposite sex (3.80), although they also fit into the normative indicators of average values, but do not reach a high level. The overall level of self-trust is 43.54 points (table 1). selves in intellectual activity, but less - in relationships with young children.

\section{Empathy manifestation in adolescence}

Empathy diagnostics by I. M. Yusupov (Yusupov I.M., 2004) was used to identify the level of empathic tendencies in adolescents. According to the results of the questionnaire, the following scales can be distinguished: the level of

Table 1. Average values of self-trust in the whole sample

\begin{tabular}{|l|r|r|}
\hline \multicolumn{1}{|c|}{ Parameters } & \multicolumn{1}{c|}{ Mean } & \multicolumn{1}{c|}{ Standart deviation } \\
\hline Self-trust in educational activities & 3,96 & 1,082 \\
\hline Self-trust in intellectual activities & 4,04 & 1,099 \\
\hline Self-trust in everyday life & 4,02 &, 987 \\
\hline Self-trust in relationships with friends & 4,26 & 1,036 \\
\hline Self-trust in relationships with younger pupils & 3,85 & 1,232 \\
\hline Self-trust in relationships with teachers & 3,92 & 1,151 \\
\hline Self-trust in relationships with family members & 4,28 & 1,172 \\
\hline Self-trust in relationships with children & 4,01 & 1,394 \\
\hline Self-trust in relationships with parents & 4,11 & 1,239 \\
\hline Self-trust in relationships with representatives of the opposite sex & 3,80 & 1,398 \\
\hline Self-trust in ability to have fun & 4,22 & 1,149 \\
\hline
\end{tabular}

The analysis of self-trust manifestation features in groups of teenagers divided on a social situation of development allowed to reveal their differences. Thus, teenagers from full families scored the highest points in terms of self-trust. In particular, they trust themselves in educational, intellectual activities, in relations with teachers, younger pupils, parents and in the ability to have fun more, than teenagers from the orphanage. Adolescents from full families trust themselves in relations with teachers, young children and parents more, than teenagers from incomplete families. Teenagers from incomplete families more than teenagers from the orphanage, trust them- empathy towards parents, elderly people, children, book/sinema heroes, unfamiliar people, as well as the general level of empathy. For the whole sample, the overall level of empathy is within the average values (48.3 points). In the structure of empathy across the sample, the highest number of points scored the level of empathy towards parents (8.62), towards children (8.47) and unfamiliar people (8.37). The lowest number of points was found in empathy towards book/ sinema heroes (5.91) (table 2).

Empathy among adolescents, brought up in different social situations, also varies. Empathy to unfamiliar people is higher in adolescents from 
Table 2. Average values of empathy in the whole sample

\begin{tabular}{|l|r|r|}
\hline \multicolumn{1}{|c|}{ Parameters } & Mean & \multicolumn{1}{c|}{ Standart deviation } \\
\hline Empathy towards parents & 8,62 & 3,19 \\
\hline Empathy towards animals & 5,35 & 2,406 \\
\hline Empathy towards elderly & 7,48 & 2,707 \\
\hline Empathy towards children & 8,47 & 3,235 \\
\hline Empathy towards heroes of works of art & 5,91 & 2,836 \\
\hline Empathy towards strangers and unfamiliar people & 8,37 & 3,41 \\
\hline
\end{tabular}

complete and incomplete families $(p<0.05)$ compared with adolescents from an orphanage. Adolescents from incomplete families more than adolescents from the orphanage $(\mathrm{p}<0.05)$ and full families $(\mathrm{p}<0.05)$, are able to be compassionate to parents.

Correlation analysis between self-trust and empathy level in adolescence
Correlation analysis between self-trust and empathy in groups, divided by family situation of development, found that the greatest number of correlations was obtained in the group of adolescents from single-parent families (20). Most of the connections are formed with empathy to parents (6), children (4) and with the general level of empathy (3). All correlations are positive

Table 3. Correlations between self-trust and empathy in incomplete (single-parent) families

\begin{tabular}{|l|r|r|r|r|r|r|}
\hline \multicolumn{1}{|c|}{ Parameters } & $\begin{array}{c}\text { General } \\
\text { level of } \\
\text { empathy }\end{array}$ & $\begin{array}{c}\text { Empathy } \\
\text { towards } \\
\text { parents }\end{array}$ & \multicolumn{1}{c|}{$\begin{array}{c}\text { Empathy } \\
\text { towards } \\
\text { elderly }\end{array}$} & $\begin{array}{c}\text { Empathy } \\
\text { towards } \\
\text { children }\end{array}$ & $\begin{array}{c}\text { Empathy } \\
\text { towards } \\
\text { heroes of } \\
\text { works of art }\end{array}$ & $\begin{array}{c}\text { Empathy } \\
\text { towards } \\
\text { strangers }\end{array}$ \\
\hline $\begin{array}{l}\text { Self-trust in relationships } \\
\text { with teachers }\end{array}$ & 0,297 & 0,241 & $-0,043$ & 0,367 &, $595^{* *}$ &, $441^{*}$ \\
\hline $\begin{array}{l}\text { Self-trust in relationships } \\
\text { with younger pupils }\end{array}$ &, $448^{*}$ &, $831^{* *}$ &, $475^{*}$ & 0,279 & 0,277 & 0,123 \\
\hline $\begin{array}{l}\text { Self-trust in relationships } \\
\text { with children }\end{array}$ &, $605^{* *}$ &, $695^{* *}$ & $-0,02$ &, $671^{* *}$ &, $581^{* *}$ & 0,332 \\
\hline $\begin{array}{l}\text { Self-trust in relationships } \\
\text { with friends }\end{array}$ & $-0,155$ &, $400^{*}$ & 0,188 & $-0,245$ & $-0,231$ & $-0,026$ \\
\hline $\begin{array}{l}\text { Self-trust in relationships } \\
\text { with representatives of } \\
\text { the opposite sex }\end{array}$ & 0,211 & $-0,359$ & $-0,043$ & 0,271 & $-0,035$ &, $403^{*}$ \\
\hline $\begin{array}{l}\text { Self-trust in the ability to } \\
\text { have fun }\end{array}$ & 0,24 & 0,171 &,$- 495^{*}$ &, $409^{*}$ & 0,311 & 0,171 \\
\hline $\begin{array}{l}\text { Self-trust in relationships } \\
\text { with family members }\end{array}$ &, $436^{*}$ &, $809^{* *}$ & 0,23 &, $422^{*}$ & 0,24 & 0,198 \\
\hline $\begin{array}{l}\text { Self-trust in relationships } \\
\text { with parents }\end{array}$ & 0,109 &, $709^{* *}$ &, $450^{*}$ & 0,017 & $-0,022$ & $-0,231$ \\
\hline General level of self-trust & 0,377 &, $574^{* *}$ & 0,13 &, $434^{*}$ & 0,347 & 0,176 \\
\hline
\end{tabular}

**. Correlation is significant at the 0.01 level (2-tailed).

*. Correlation is significant at the 0.05 level (2-tailed). 
$(\mathrm{p}<0.001)$. Self-trust in relationships with young children is most included in correlations with empathy (table 3).

Slightly less correlations were found in the group of adolescents from the orphanage (16). Just as in the group of single-parent families, the greatest number of connections formed empathy to parents (4). Correlations are also positive, mainly at $\mathrm{p}<0.001$. Self-trust in relationships with younger pupils is more involved in connections with empathy (table 4).

There are far fewer links of self-trust and empathy (8) in a subgroup of adolescents from complete families. In this group, there are no correlations of empathy towards parents, children and the elderly with indicators of self-trust, which in other groups act as centers of integration. The general level of empathy is most involved in rela-

Table 4. Correlations between self-trust and empathy in orphanages

\begin{tabular}{|c|c|c|c|c|c|c|c|}
\hline Parameters & $\begin{array}{l}\text { General } \\
\text { level of } \\
\text { empathy }\end{array}$ & $\begin{array}{l}\text { Empathy } \\
\text { towards } \\
\text { parents }\end{array}$ & $\begin{array}{l}\text { Empathy } \\
\text { towards } \\
\text { animals }\end{array}$ & $\begin{array}{l}\text { Empathy } \\
\text { towards } \\
\text { elderly }\end{array}$ & $\begin{array}{l}\text { Empath } \\
\text { toward } \\
\text { childre }\end{array}$ & $\begin{array}{l}\text { Empathy } \\
\text { towards } \\
\text { heroes of } \\
\text { works of } \\
\text { art }\end{array}$ & $\begin{array}{l}\text { Empathy } \\
\text { towards } \\
\text { strangers }\end{array}$ \\
\hline $\begin{array}{l}\text { Self-trust in intel- } \\
\text { lectual activities }\end{array}$ & $-0,146$ & 0,013 & $-0,374$ & $-0,171$ &,$- 479^{*}$ & $-0,245$ & $-0,297$ \\
\hline $\begin{array}{l}\text { Self-trust in rela- } \\
\text { tionships with } \\
\text { teachers }\end{array}$ & $-0,002$ & $-0,075$ &, $508^{*}$ & $-0,018$ & 0,196 & 0,339 & 0,16 \\
\hline $\begin{array}{l}\text { Self-trust in every- } \\
\text { day life }\end{array}$ &, $485^{*}$ & 0,296 & 0,397 & 0,065 &, $576^{* *}$ &, $459^{*}$ & 0,316 \\
\hline $\begin{array}{l}\text { Self-trust in rela- } \\
\text { tionships with } \\
\text { younger pupils }\end{array}$ &, $520^{*}$ &, $474^{*}$ & 0,069 & ,496* & 0,056 & 0,294 & ,490* \\
\hline $\begin{array}{l}\text { Self-trust in rela- } \\
\text { tionships with } \\
\text { friends }\end{array}$ & $-0,048$ & 0,327 &,$- 461^{*}$ & $-0,158$ &,$- 449^{*}$ & $-0,266$ & $-0,05$ \\
\hline $\begin{array}{l}\text { Self-trust in rela- } \\
\text { tionships with rep- } \\
\text { resentatives of the } \\
\text { opposite sex }\end{array}$ & 0,304 &, $562^{* *}$ &,$- 520^{*}$ &, $610^{* *}$ & 0,149 & $-0,101$ & $-0,001$ \\
\hline $\begin{array}{l}\text { Self-trust in rela- } \\
\text { tionships with fam- } \\
\text { ily members }\end{array}$ & 0,4 &, $683^{* *}$ & $-0,178$ & 0,325 & 0,422 & 0,172 & 0,049 \\
\hline $\begin{array}{l}\text { General level of } \\
\text { self-trust }\end{array}$ & 0,369 &, $573^{* *}$ & $-0,377$ & 0,141 & 0,009 & $-0,092$ & 0,153 \\
\hline
\end{tabular}

**. Correlation is significant at the 0.01 level (2-tailed).

*. Correlation is significant at the 0.05 level (2-tailed). 
Table 5. Correlations between self-trust and empathy in full families

\begin{tabular}{|c|c|c|c|c|}
\hline Parameters & $\begin{array}{l}\text { General level of } \\
\text { empathy }\end{array}$ & $\begin{array}{l}\text { Empathy to- } \\
\text { wards parents }\end{array}$ & $\begin{array}{l}\text { Empathy to- } \\
\text { wards animals }\end{array}$ & $\begin{array}{l}\text { Empathy towards } \\
\text { strangers }\end{array}$ \\
\hline $\begin{array}{l}\text { Self-trust in educational activi- } \\
\text { ties }\end{array}$ & $-0,092$ &,$- 353^{*}$ & 0,054 & $-0,092$ \\
\hline $\begin{array}{l}\text { Self-trust in intellectual activi- } \\
\text { ties }\end{array}$ & $-0,02$ & $-0,262$ & $-0,051$ &,$- 306^{*}$ \\
\hline $\begin{array}{l}\text { Self-trust in relationships with } \\
\text { younger pupils }\end{array}$ &,$- 290^{*}$ & $-0,192$ & $-0,019$ & 0,042 \\
\hline $\begin{array}{l}\text { Self-trust in relationships with } \\
\text { friends }\end{array}$ &,$- 589^{* *}$ & $-0,135$ &,$- 389^{* *}$ & 0,044 \\
\hline $\begin{array}{l}\text { Self-trust in relationships with } \\
\text { representatives of the opposite } \\
\text { sex }\end{array}$ &,$- 308^{*}$ & $-0,28$ & $-0,114$ & $-0,031$ \\
\hline Self-trust in ability to have fun & $-0,221$ & 0,175 &,$- 381^{* *}$ & $-0,051$ \\
\hline General level of self-trust &,$- 296^{*}$ & $-0,178$ & $-0,259$ & $-0,083$ \\
\hline
\end{tabular}

tion to self-trust (4), all correlations are negative $(\mathrm{p}<0.05, \mathrm{p}<0,001)$ (table 5).

In General, the revealed correlations of empathy with the manifestations of self-trust show, that empathy contributes to the manifestations of self-trust in the same spheres, and prevent the manifestations of self-trust in the opposite spheres.

\section{Discussion}

In older adolescence, the focus of trust is shifted to relationships with peers and those whom teenagers consider to be close people. The study of self-trust in different spheres of life in adolescence has allowed us to identify that most teenagers show self-trust in their relationships with friends, family and the ability to have fun, which corresponds to the tasks of adolescent period of psychological development. It is also consistent with previous studies that the earliest form of self-trust is connected with relationships with loved ones, which promotes attachment and is a prerequisite for positive development (E.Erikson, 1995; Sakai, A., 2010). The greatest difficulties teenagers experience in self-trust in a relationship with representatives of the opposite sex, younger pupils and teachers. Since adolescence is a transitional period from childhood to adulthood, these spheres of relations undergo changes, they are reconstructed (elements of more adult perception and behavior are included in relations with the opposite sex; the relationship with younger pupils also undergo changes, as adolescents move away from this group and no longer identify with it; 
relationships with teachers require a transition to another level of interaction). These changes, on the one hand, lead to new constructs of age, including changings in self-trust, and on the other hand, lead to difficulties in the formation of these tumors (Gorina T.S., 2014).

The study of social situation of development in adolescence revealed very significant points for further investigations. Children from orphanage have the lowest rates of self-trust in educational and intellectual sphere, in relations with younger pupils, family members, with parents and in the ability to have fun. Adolescents from full families have the highest, among the study groups, indicators in all areas of self-trust. In the group of adolescents from single-parent families, the lowest rates are obtained by selftrust in relationships with teachers, friends, representatives of the opposite sex and in relations with young children.

These results are in part consistent with the literature, which confirms the varying degree of self-trust in relation to the conditions offered by the world around us. There is a violation of trust relations as a manifestation of the traumatic experience of orphans (Zaripova Y.R., 2008). Trusting relationships are almost absent in relation to other people in adolescents from orphanages, they often show distrust and expectation of trouble, especially for peers. At the same time, the research notes that just $12.5 \%$ of orphanage children do not have deprivation of trust, and therefore have the opportunity to form a trusting social relations. The remaining $87.5 \%$, along with deprivation of trust show unformed value attitude to themselves, which is expressed in the lack of confidence (Skripkina T.P., 2008).

Parent's divorce as the reason of one of the parent's absence leads to a serious psychological shock, experienced by children. This can lead to a breakdown in child-parent relationships, which undoubtedly affects the manifestation of all components of trust. And since interpersonal trust and self-trust is the basis for the successful psychological development, it can lead to problems with communication and mental health, conflicts and lack of confidence, the misunderstanding and diffidence in the future. The psychological trauma, caused by divorce of parents, can manifest serious problems in adolescence.

The researchers note that adolescents who grew up in divorced families have also low selfesteem along with low level of self-trust (Buyanov M.I., 1988).

According to G. Figdor, in adolescent boys with low self-esteem, fathers are often inattentive to them and children do not trust them (Istratova O.N., 2007). Thus, the trauma of parting with parents, deprivation of parental influence can act as a factor that violates the formation of trust, which was confirmed in our study. Empathy in adolescents, living in different social conditions, also differs. Empathy towards unfamiliar people is higher in adolescents from families compared to adolescents from orphanage. Probably, conditions of communication in families are created for for- 
mation of empathy towards others, including unfamiliar people. Also, teenagers from singleparent families more than teenagers from orphanage and full families are able to empathize with parents.

This is partly consistent with the literature data, that adolescent's relationships with their mother influence the formation of empathy. Thus, those children, who were not brought up by their mother had a very low level of empathy. It was also found that if a teenager had a closer emotional connection with his grandparents, and not with his mother, the empathy for strangers and unfamiliar people is at a lower level (Sityaeva S.M., 2013). It is worth noting the great ability to recognize the mother's emotional states by children in single-parent families. In case of less warmth and, accordingly, less satisfaction with relationships with mother, children have to adapt to her condition, thereby learning to recognize the emotions of other people better (Golovey L.A., 2016). Studies by Pashina E. P., Ryazanova A. H. in the field of empathy show that orphans have an extremely poor reserve of emotional shades, the colors of the emotional sphere are monotonous, they are worse at recognizing emotions, they are characterized by high anxiety and low level of empathy (Pashina E.P., 1993).

\section{Conclusions}

1) manifestations of self-trust differ depending on the spheres of life and conditions of social situation of development. In general, ado- lescents, living in full families have a higher level of self-trust. Most of all they trust themselves in the sphere of relations with close people (with family and parents), then in the educational and intellectual sphere and in the sphere of relations with peers. To a lesser extent they trust themselves in relations with younger;

2) adolescents, living in single-parent families, show less self-trust, than adolescents from full families and in some cases, than adolescents from orphanage. Least of all they trust themselves in the sphere of relations with teachers and young children;

3) adolescents, living in orphanages, show less self-trust in all spheres of life than teenagers from full families. The lowest indicators of self-trust are typical for them in educational activities, intellectual activity, in relations with teachers, with parents and in ability to have fun;

4) the severity of empathy level corresponds to the average values. Empathy in adolescents, living in different social conditions, also varies. The highest overall level of empathy is observed in adolescents from single-parent families, as well as all indicators in the structure of empathy, except empathy towards elderly people. Empathy towards unfamiliar people is higher in adolescents from families compared to adolescents from the orphanage. Probably, there is a good situation for formation of empathy towards others, including unfamiliar people, in family conditions. Also, teenagers from single-parent families are able to empathize with parents more, than 
teenagers from the orphanage and full families.

5 ) the largest number and strength of selftrust and empathy correlations is found in the group of adolescents from orphanage, while in the group of adolescents from full families, the least is found, and they are all negative. In groups of adolescents who have experienced the trauma of parting with one or both parents, empathy towards them remains, moreover, it forms the largest number of correlations with self-trust. That is that the acceptance of the fact of family deprivation, acts as a resource of self-trust. This is probably a protective mechanism of the psyche. In general, the revealed correlations of empathy with the manifestations of self-trust show that empathy contributes to the manifestations of self-trust in the same spheres, and prevent the manifestations of self-trust in the opposite spheres.

\section{Acknowledgments}

We thank the adolescents participating in our research. Also we thank Public School №86, Public School of Saint Petersburg State University and Orphanage №3 administrations for their help in organization of the research.

\section{References :}

1. Baltes P. (1987). Theoretical propositions of lifespan developmental psychology. Developmental psychology, Vol. 23, pp. 611-626.

2. Baron-Cohen S. (2004). The empathy quotient: An investigation of adults with Asperger Syndrome or high functioning autism, and normal sex differences Journal of Autism and Developmental Disorders, Vol. 34 (2d edition), pp. 163-175.

3. Benenson J. F. (2008). Sex differences in help-seeking appear in early childhood. British Journal of Developmental Psychology, V o 1. 26, pp. 163-169.

4. Bozhovich L. I. (2005). Problemy formirovaniya lichnosti [Problems of personality formation]. Moscow: Education.

5. Bronfenbrenner U.

(1970).Two worlds of childhood: U.S. and U.S.S.R. New York: Russell Sage Foundation.

6. Buyanov M.I. (1988). Rebenok iz ntblagopoluchnoi sem'i: zapiski detskogo psikhiatra: kniga dlya ychitelei I roditelei [A child from a dysfunctional family: child psychiatrist's notes: a book for teachers and parents]. Moscow: Education.

7. Castaldo S. (2002). Meanings of Trust: a Meta Analysis of Trust Definitions. Paper presented at Second Euram Conference. Stockholm.

8. Coleman J. (1988). Social Capital in the Creation of Human Capital. The American Journal of Sociology, Vol. 94, pp. S95-S120.

9. Erikson, Erik H. (1993). Childhood and Society. New York, NY: W. W. Norton \& Company.

10. Fukuyama F.

(1995). Trust: The Social Virtues and the Creation of Prosp erity, New York, NY: Free Press, 1995,

11. Furmanov I.A. (2009) Psikhologiya deprivirivannogo rebenka [Deprivated child psychology]. Moscow: Vlados.

12. Garland, A.F. (1994). Psychological correlates of help-seeking attitudes among children and adolescents. The American Journal of Orthopsychiatry, Vol. 64, pp. 586-593.

13. Gavrilova T.P. (1981). Analiz empatiynikh perezhivaniy mladshikh shkolnikov I mladshikh podrostkov [Analysis of the empathic experiences of younger students and younger teenagers]. Bodalev M. (Ed). Moscow: Pedagogy.

14. Gebert D. (2006). Organizatsionnaya psikhologiya. Chelovek I organizatsiya [Organisational Psychology. Human and organization]. Khabarovsk: Gumanitarniy centr.

15. Golovey L.A. (2016). Psikhologiya razvitiya I vozrast- 
naya psikhologiya: uchebnik I praktikum dlya prikladnogo bakalavriata [Developmental Psychology and the psychology of aging: a textbook and workshop for applied baccalaureate]. L. A. Golovey (Ed). Moscow: Yurayt.

16. Golovey L.A., Vasilenko V.E., Savyonisheva S.S. (2016). Struktura sem'i i semeinoe vospitanie kak faktori razvitiya lichnosti doshkolnika [Family structure and bringing up in families as a factor of child development]. Social psychology and society, Vol.2, pp.5-18 [in russian].

17. Golub O.V. (2004). Doverie k sebe kak vnutrilichnostnoe obrazovanie starshikh podrostkov [Self-trust as an intrapersonal feature of older adolescents]. Extended abstract of candidate's thesis. Rostov [in russian].

18. Gorina, T.S. (2014). The Theoretical Set-up for Studying Trust in The educational environment, Fundamental Research, 11-8: 1845-1851. URL: https:// fundamentalresearch.ru/ru/article/view?id=35860[in Russian].

19. Havighurst R. (1972). Developmental tasks and education. New York: McKay Company.

20. Isaaks J., Soglian F., Hoffman E. (2015) . Confidant Relations in Italy. Europe's Journal of Psychology, Vol. 11, pp. 50-62.

21. Istratova O.N. (2007). Praktikum po detskoi psikhokorrekcii: igry, uprazhneniya, tekhniki [Practicum in child psychotherapy: games, exercises, techniques]. Rostov-amDon: Phoenix.

22. Jalava J. (2003). From Norms to Trust. European Journal of Social Theory, Vol. 6, pp. 173-190.

23. Jones D.C. (1991). Friendship satisfaction and gender: An examination of sex differences in contributors to friendship satisfaction. Journal of Social and Personal Relationships, Vol. 8(2), pp. 167-185.

24. Karabanova, O.A. (2010). Socialnaya situatsiya razvitiya rebenka - klyuchevoi concept sovremennoi psikhologii razvitiya [Social Situation of Child's Development - the Key Concept of the Modern Developmental Psychology]. Psychology in Russia: State of Art, Vol. 3, pp. $130-153$.
25. Kinderman, Th. (1988). Developmental tasks as organizers of childrens ecologies: mother's contingencies as children learn to walk, eat and dress. Child development within culturally structured environments: social co-construction and environmental guidance in development, V o 1 . 2, pp. 66-105.

26. Kle M. (1997). Psikhologiya podrostka [Adolescent psychology]. Moscow: Russian pedagogical society.

27. Kon I.S. (2004). Druzhba [Friendship]. St.P.: Piter.

28. Kurdek, L.A. (2002). Predicting the timing of separation and marital satisfaction: An eight-year prospective longitudinal study. Journal of Marriage and the Family, Vol. 64(1), pp.163-179.

29. Langmeier, J., Matějček, Z. (1976). Psychological Deprivation in Childhood. University of Queensland Press.

30. Leonova I.U. (2015) Doverie: ponyatiya, vidy I funktsii [Trust: definitions, types and functions] // Udmurtian University Journal, Vol. 25, pp.34-41.

31. Obukhova L.F. (2013). Vozrastnaya psikhologiya: uchebnik dlya bakalavrov [Psychology of ageing: textbook for students]. Moscow: Urait.

32. Pashina E. P. (1993). Osobennosti emotsionalnoi sfery $u$ vospitannikov I sotrudnikov detskogo doma [Features of the emotional sphere of pupils and workers of the orphanage]. Psychological journal, Vol.1, pp. 44-52.

33. Pereverzeva I.A. (2000). Problrma doveriya $v$ sfere biznessa [The problem of trust in business]. International psychology Journal, Vol. 12, pp. 84-93.

34. Prikhozhan A.M. (2007). Psikhologiya sirotstva [Psychology of orphanhood]. St.P.: Piter.

35.Rice F. Ph. (2010). Psikhologiya podrostkovogo $i$ yunosheskogo vozrasta [The psychology of adolescence]. $\mathrm{SPb}$.: Peter.

36. Rotenberg, K. J. (1991). Children's interpersonal trust: Sensitivity to lying, deception, and promise violations. New York; Springer.

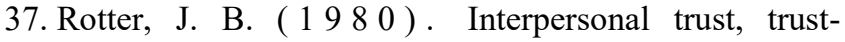
worthiness, and gullibility. American Psychologist, Vol. 35(1), pp. 1-7. 
38. Rousseau Jean-Jacques (1981). Pedagogicheskiye sochineniya [Pedagogical essayes]. Moscow: Pedagogy.

39. Rutkovsky B.A. (1967). Ponyatiye doveriya $v$ marksistskoy etike [The phenomenon of trust in marksist's ethics]. Extended abstract of candidate's thesis. Kiev.

40. Sakai, A. (2010). Children's sense of trust in significant others: Genetic versus environmental contributions and buffer to life stressors. Interpersonal Trust during Childhood and Adolescence. Cambridge: Cambridge University Press. doi:10.1017/CBO9780511750946.004

41. Shibutani T. (1961). Society and personality: an interactionist approach to Social Psychology, NJ: Prentice hall.

42. Sho R.B. (2000). Klyuchi $k$ doveriyu v organizatsii: rezultativnost, poryadochnost, proyavleniye zaboti [Keys to trust in organization: performance, integrity, caring]. Moscow: Delo.

43. Sityaeva, S.M. (2013). Psikhologicheskiye osobennosti empatii podrostkov [Psychological characteristics of empathy in adolescents]. Amur scientific Bulletin, Vol. 3, pp. 151-158.

44. Skripkina T.P. (2000). Psikhologiya doveriya: uchebnoye posobiye dlya studentov vysshikh pedagogicheskikh uchebnykh zavedeniy [Psychology of trust: textbook for students. high. ped. Institutions]. Moscow: Academy.

45. Starr, L. R. (2008). Differentiating interpersonal correlates of depressive symptoms and social anxiety in adolescence: Implications for models of comorbidity. Journal of Clinical Child and Adolescent Psychology, Vol. 37(2), pp. 337-349.

46. Sztompka P. (1999). Trust: A Sociological Theory. Cambridge, UK: Cambridge University Press.

47. Ullmann-Margalit E. (2004).

Trust, distrust, and in between. New York: Russel Sage Foundation.

48. Vangelisti, A.L. (1997). Revealing family secrets: The influence of topic, function, and relationships. Journal of Social and Personal Relationships, Vol. 14(5), pp. 679-705.

49. Yusupov I.M. (2004). Psychologuya empatii (teoreticheskiye I prikladniye aspekty) [Psychology of empathy (theoretical and applied aspects)]. Extended abstract of candidate's thesis. Saint-Petersburg.

50. Zaripova Y.R. (2008). Narusheniye doveritelnykh otnosheniy kak proyavlenie travmaticheskogo opyta podrostkov-vospitannikov detskogo doma [Trust relationships violation as traumatic experience manifestation in adolescents from orphanages]. Saint Petersburg University Press, Vol.12, pp. 252-257.

51. Zinchenko V.P. (2001). Psychologiya doveriya [Psychology of trust]. Samara: SIOKPP.

\section{Данилова Юлія Юріївна}

Кандидат психологічних наук, Санкт-Петербурзький державний університет, м. Санкт-Петербург (Російська Федерачія)

\section{ДОВІРА ДО СЕБЕ У ВЗАЕМОЗВ'ЯЗКУ 3 ЕМПАТІЕЮ ЗАЛЕЖНО ВІД СОЦАЛЬНОЇ СИТУАЦЇ̈ РОЗВИТКУ В ПІДЛІТКОВОМУ ВІЩІ}

Анотація. У статті проаналізований рівень довіри до себе у зв'язку з рівнем вираженості емпатії в залежності від соціальної ситуації розвитку в підлітковому віці. Виявлені особливості довіри до себе в найважливіших сферах життя і життєдіяльності різних категорій людей у підлітках, що проживають у повних та неповних сім'ях, а також у дитячих домах. Виборка: 286 підлітків 3 СанктПетербургу, Россія, у віці 14-16 лет (126 хлопчиків; 160 дівчат), в тому числі 97 підлітків 3 дитячого будинку (46 хлопчиків; 51 дівчат), 104 дитини з повних сімей (53 хлопчики; 51 дівчат); 85 підлітків з неповних сімей (40 хлопчиків; 45 дівчат). Для дослідження рівня довіри до себе в важливих сферах життя підліт- 
ків використовувався модифікований для цього віку опитувальник довіри до себе Т. П. Скрипкіной. Для діагностики рівня вираженості емпатії використана методика I. М. Юсупова. Аналіз даних включенає описову статистику, Т-тест Стьюдента, кореляційний аналіз за Спирменом. Результати нашого дослідження показують, що довіра до себе в підлітковому віці проявляється по-різному в різних сферах життя. Довіра до себе найбільше виражена в проблемних для даного віку сферах: навчальна сфера і відносини з протилежним полом. Довіра до себе у взаємостосунках з однолітками та родиною знаходиться на високому рівні. Соціальна ситуація розвитку впливає на прояв довіри до себе: у підлітків із повної сім’ї показник довіри до себе вище. Фокус емпатії також варіюється в підлітків 3 повних сімей і тих, хто переживає травму розлучення з батьками. Результати показують важливість не тільки наявності, але й важливість складу сім’ї для успішного психологічного, соціального та соціального розвитку в підлітковому віці.

Ключові слова: підлітковий вік, довіра до себе, емпатія, батьківська депривація, сім'я, дитячий будинок, соціальна ситуація розвитку.

\section{Данилова Юлия Юрьевна}

Кандидат психологических наук, Санкт-Петербургский государственный университет, 2. Санкт-Петербург (Российская Федерация)

\section{УРОВЕНЬ ДОВЕРИЯ К СЕБЕ В СВЯЗИ С УРОВНЕМ ВЫРАЖЕННОСТИ ЭМПА- ТИИ В ЗАВИСИМОСТИ ОТ СОЦИАЛЬ- НОЙ СИТУАЦИИ РАЗВИТИЯ В ПОД- РОСТКОВОМ ВОЗРАСТЕ}

Аннотация. В статье проанализирован уровень доверия к себе в связи с уровнем выраженности эмпатии в зависимости от социальной ситуации развития в подростковом возрасте. Изучены особенности доверия к себе в наиболее важных сферах жизнедеятельности и эмпатия к различным категориям людей у подростков, проживающих в полных и неполных семьях, а также в детских домах. Выборка: 286 подростков из Санкт-Петербурга, Россия, в возрасте 14-16 лет (126 мальчиков; 160 девочек), в том числе 97 подростков детского дома (46 мальчиков; 51 девочка), 104 ребенка из полных семей (53 мальчика; 51 девочка); 85 подростков из неполных семей (40 мальчиков; 45 девочек). Для исследования уровня доверия к себе в значимых сферах жизни подростков использовался модифицированный для данного возрастного периода опросник доверия к себе Т. П. Скрипкиной. Для диагностики уровня выраженности эмпатии использовалась методика И. М. Юсупова. Анализ данных включал описательную статистику, Т-тест Стьюдента, корреляционный анализ по Спирмену. Результаты нашего исследования показывают, что доверие к себе в подростковом возрасте не 
одинаково проявляется в различных сферах жизни. Доверие к себе наименее выражено в проблемных для данного возрастного периода областях: учебной сфере и в отношениях с противоположным полом. Доверие к себе в сферах взаимоотношений со сверстниками и семьей находится на высоком уровне. Социальная ситуация развития влияет на проявление доверия к себе: у подростков из полных семей все показатели доверия к себе выше. Фокус эмпатии также варьируется у подростков из полных семей и тех, кто пережил травму расставания с родителями. Полученные данные показали важность не только наличия, но и состава семьи для успешного психологического, социального и эмоционального развития в подростковом возрасте.

Ключевые слова: подростковый возраст, доверие к себе, эмпатия, родительская депривация, семья, детский дом, социальная ситуация развития.
Дата отримання статті: 12.03.2019

Дата рекомендації до друку: 25.03.2019

Дата оприлюднення: 14.05.2019 